\title{
ROSE Cluster 7
}

National Cancer Institute

\section{Source}

National Cancer Institute. ROSE Cluster 7. NCI Thesaurus. Code C121986.

Gene expression cluster 7 as determined by Recognition of Outliers by Sampling Ends (ROSE) in high-risk B-precursor acute lymphoblastic leukemia. 